\title{
Machine Elements - Revision and Outlook for Design Education
}

\author{
W. Ernst Eder, \\ Professor (Retired), Mechanical Engineering, Royal Military College of Canada \\ Home: 107 Rideau Street, Kingston, ON K7K 7B2, (613) 547-5872 \\ eder-e@rmc.ca
}

\begin{abstract}
Technical Systems (TS) are products intended to perform a task. Machine elements (ME) are technical systems of the two (of four) lower complexity levels, mostly mechanical engineering items. The literature presents loosely classified listings, but hydraulic, thermal or control elements usually do not appear.

The dominating TS-internal process concerns energy, characterized by a static and a dynamic property. ME carry functions, and have active connections to other constructional parts. A systematic classification of $M E$ according to functions is presented. Systematic classification and variation assists creativity, and can produce many hundreds of alternatives, but increases demands for suitable selection and evaluation.
\end{abstract}

\section{Introduction - General Context}

Machine Elements has long been a staple subject for mechanical engineering education, and an extensive literature exists, e.g. $[1,2,3,4]$. Nevertheless, there is a general lack of a systematic classification. The literature presents partly-ordered listings, often with examples of existing machine elements (ME), and extensive engineering science analysis, with little attempt at revealing the underlying principles of action, i.e. understanding how they work and what properties they possess. After the Grinter Report [5], and with the development of digital computers, the tendency has been to neglect the examples, and to emphasize the analytical methods.

For many years it has been recognized that the curriculum changes introduced in the 1960's, as a result of the Grinter Report [5], were in some ways counterproductive. Quoting from Grinter (Appendix): 'The Committee considers that scientifically oriented engineering curricula are essential to achieve these ends and recommends the following means of implementation.' This major report then recommended ten 'means of implementation' (something helpful in achieving a desired end, Merriam-Webster Dictionary) of which the third is interesting in the context of this paper, it reads:

'3. An integrated study of engineering analysis, design, and engineering systems for professional background, planned and carried out to stimulate creative and imaginative thinking, and making full use of the basic and engineering sciences.' [5] Scientists can usefully specialize in a small region of the forefront of knowledge [6]. Engineers need a wide range of existing recorded information and knowledge [7], and need to know (as tacit, internalized knowledge [7a]) the contexts and relationships (a) among the items of knowledge, and (b) the relevance to society, culture, economics, politics, the quality of life, etc. Engineering is not just 'applied science', it has many other tasks and responsibilities, including societal, economic, law-related, innovative, management and coordinating functions [7]. Even in its technical aspects, engineering needs information that is not available or is even incapable of formulation in scientific terms [8,9]. Among other attributes, engineering is a reflective activity $[10,10 \mathrm{a}]$. A task for engineers is to provide the basis for making useful products, i.e. goods and services summarized as designing. Problem solving alone is not enough. Designing has its own procedures, of which problem solving (see figure 1) is a sub-set. Problem solving includes analysing (at a verbal conceptual level in operations Op-H3.1 and Op-H3.3, and also using engineering sciences in operation Op-H3.3), synthesizing (in operation Op-H3.2), judging (Op-H3.3), representing and communicating (in words, diagrams, pictures, symbols, mathematics, gestures, etc., Op-H3.4), verifying and checking (Op-H3.6), and handling information (Op-H3.5).

Designing is not fully predictable. Nevertheless, procedures and methods for design engineering can be proposed, and related to ways of modeling systems. The needs to learn such design procedures in a more formalized way, especially to enhance creativity, have been discussed, e.g. [10,11].

Technical Systems (the subjects of design engineering) are tangible products of an enterprise that have a substantial engineering content, and that are intended to be used (as operators of a transformation process, figure 2) to perform a given task, a purpose function [12]. Four degrees of complexity have been defined [13], compare figure 3:

- Complexity level IV - plant: composed of technical systems of lower complexity;

- Complexity level III - self-contained functioning system (machine): complete assemblies (TS) that can perform a task (TP), e.g. a lathe that can bu used to cut rotational workpieces;

- Complexity level II - sub-system: sub-assemblies of the parts, as intermediate stages of assembly (shafts with gear wheels, keys, bearings, etc.); 


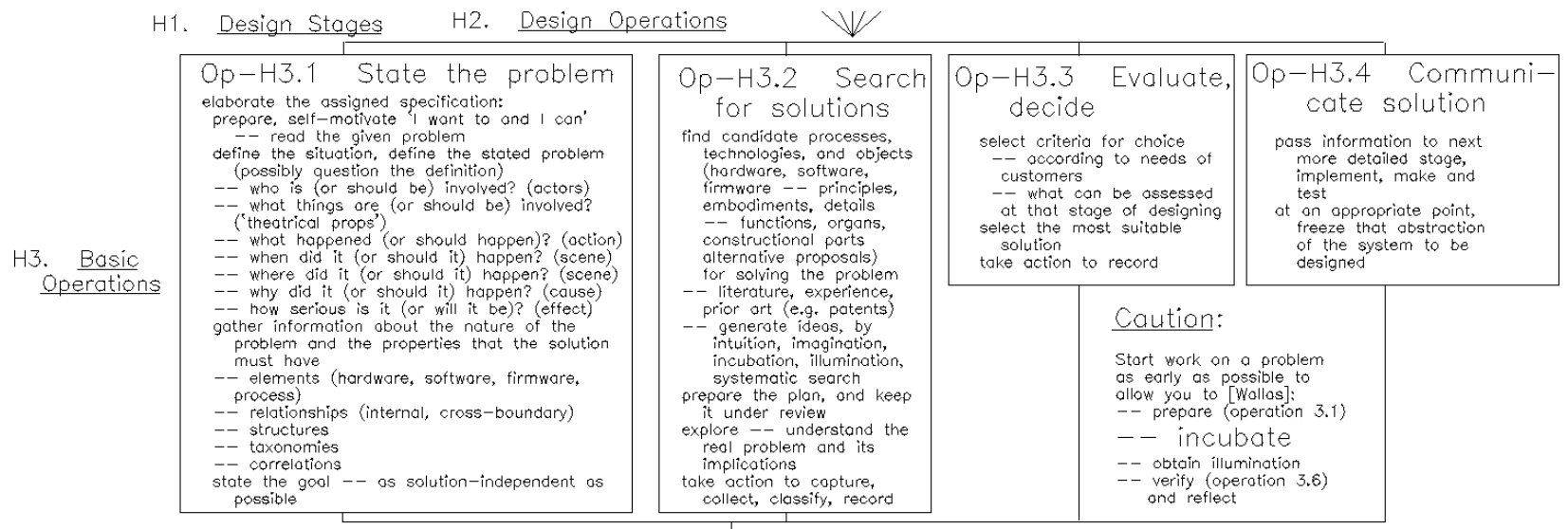

\begin{tabular}{|c|c|c|}
\hline $\begin{array}{l}\text { Op-H3.5 Prepare } \\
\text { information } \\
\text { gathering, capturing, } \\
\text { extracting, sorting, } \\
\text { classifying, oross- } \\
\text { referending, modifying } \\
\text { according to design } \\
\text { needs } \\
\text { (see also figure Ex-2) }\end{array}$ & $\begin{array}{l}\text { Op-H3.6 Verify, } \\
\text { check, reflect } \\
\text { test the solutions } \\
\text {-- mental experiment } \\
-- \text { order-of-magnitude } \\
\text { colculations } \\
\text {-- onalysis, simulation } \\
\text { check for possible } \\
\text { improvements, especially } \\
\text { of unsatisfactory elements } \\
\text { look bock - estoblish whot } \\
\text { has been leorned from the } \\
\text { solution attempt -- design } \\
\text { process gnd object } \\
\text { knowledge, experience }\end{array}$ & $\begin{array}{c}\text { Op-H3.7 Represent } \\
\text { e.g. graphical, verbol, } \\
\text { symbolic/mathematical, } \\
\text { physical oppearonce } \\
\text { model, } \\
\text { physical functionol } \\
\text { model (prototype) }\end{array}$ \\
\hline
\end{tabular}

H4. Elemental Activities H5. Elemental Operations W

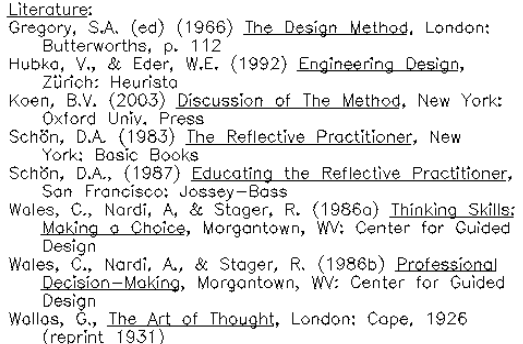

(reprint 19.31)

Figure 1 Problem Solving (Adapted from [15])

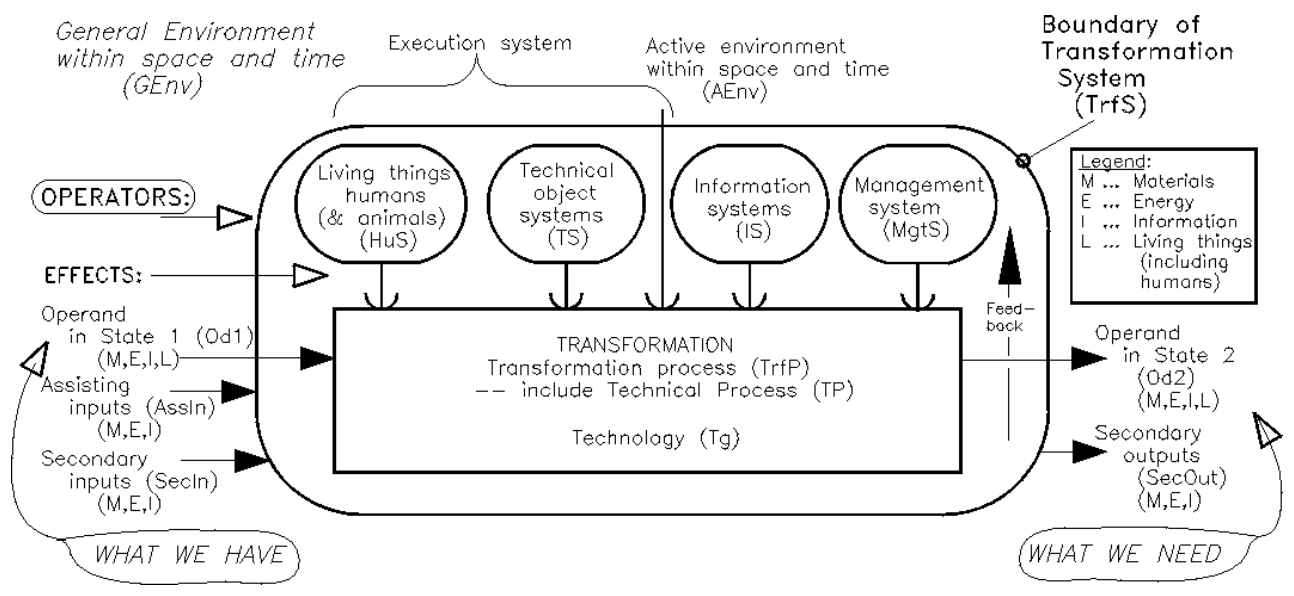

Figure 2 General Model of a Transformation System [15]

assembly groups of different complexity (the saddle, tailstock or headstock of a lathe); composite machine elements (rolling contact bearing, coupling, etc.); modules to be assembled in various configurations on a platform to supply functioning systems of different functionality;

- Complexity level I-constructional part: represent the lowest degree of complexity, mainly simple parts that are not normally capable of further disassembly, but that can usually only be subdivided by destroying the part (screws, nuts, wedges, shafts, washers, filters, electrical condensers, resistors, operational amplifiers), simple machine elements.

\section{Machine Elements - General}

As the subject of Machine Elements has grown into the curriculum by long tradition, it is mainly the purely mechanical elements that have been adopted, and they have been retained in the canon even if they have become somewhat obsolete.

Machine elements are conventionally defined as technical systems of lower complexity (levels I and II) that are frequently used as known and proven solutions for functions in technical systems. They are mostly regarded as mechanical engineering items $[1,2,3,4]$ such 


\begin{tabular}{|c|c|c|c|}
\hline $\begin{array}{l}\text { Level of } \\
\text { Complexity }\end{array}$ & $\begin{array}{l}\text { Technical } \\
\text { System }\end{array}$ & Characteristic & Examples \\
\hline$\stackrel{1}{\text { (simplest) }}$ & $\begin{array}{l}\text { Constructional } \\
\text { part }\end{array}$ & $\begin{array}{l}\text { Elemental system, usually } \\
\text { produced without } \\
\text { assembly operotions -- } \\
\text { appears in parts list }\end{array}$ & $\begin{array}{l}\text { Bolt, shaft, } \\
\text { bearing sleeve, } \\
\text { spring, washer }\end{array}$ \\
\hline II & $\begin{array}{l}\text { Group, } \\
\text { mechonism, } \\
\text { sub-assembly }\end{array}$ & $\begin{array}{l}\text { Simple system consisting } \\
\text { of constructional parts } \\
\text { that can fulfill some higher } \\
\text { functions }\end{array}$ & $\begin{array}{l}\text { Gear box, hydroulic } \\
\text { drive, spindle head, } \\
\text { brake unit, clutch, } \\
\text { shoft coupling }\end{array}$ \\
\hline |II & $\begin{array}{l}\text { Machine, } \\
\text { apporatus, } \\
\text { device, } \\
\text { equipment }\end{array}$ & $\begin{array}{l}\text { System that consists of } \\
\text { sub-assemblies and } \\
\text { constructional elements } \\
\text { (components) } \\
\text { that together perform } \\
\text { a closed function }\end{array}$ & $\begin{array}{l}\text { Lathe, motor vehicle, } \\
\text { electric motor, crone, } \\
\text { kitchen mochine }\end{array}$ \\
\hline N & $\begin{array}{l}\text { Plant, } \\
\text { equipment, } \\
\text { complex } \\
\text { machine } \\
\text { unit }\end{array}$ & $\begin{array}{l}\text { Complicated system that } \\
\text { fulfills a number of } \\
\text { functions, that consists } \\
\text { of mochines, sub-ossemblies, } \\
\text { groups and constructional } \\
\text { parts, and that constitute } \\
\text { a spatial and functiongl unity }\end{array}$ & $\begin{array}{l}\text { Hardening plant, } \\
\text { machine transfer line, } \\
\text { factory equipment, } \\
\text { refinery, underground } \\
\text { transportation system }\end{array}$ \\
\hline
\end{tabular}

Figure 3 Technical Systems Classified by Complexity [15]

as individual constructional parts (e.g. shafts - level I), or assembly groups, sub-assemblies or mechanisms (e.g. rolling contact bearings, couplings, brakes, power transmission units - level II). The literature usually presents machine elements in a loosely classified listing, with examples of construction, and details of analysis according to the engineering sciences.

In the conventional literature, such mechanical principles as (static or dynamic) hydraulic, thermal or control elements usually do not appear. Nevertheless, similarly recurring parts exist in other engineering disciplines, e.g. steel-reinforced concrete columns (civil engineering), distillation columns (chemical engineering), diodes (electronic engineering), etc. Proven elements are also used in naval architecture, aeronautical engineering, and other related fields. Most current 'machines' are not exclusively mechanical, they are hybrids reaching across the conventional boundaries of engineering disciplines - especially embracing control sub-systems using electronics, e.g. mechatronics. A wider definition to include these parts is needed, e.g. as design elements [14]. And knowing about a wide range of such constructional parts is essential to designing engineers.

\section{Machine Elements - Conceptual Analysis and Classification}

The dominating TS-internal process concerns energy. Materials and information need energy for their processing. Each type of energy is characterized by (a) a static, 'across', tension property - a 'state variable', and (b) a dynamic, 'through', rate property - a 'flow variable', see figure 4. Power is the vector product of a state variable with a flow variable.

\begin{tabular}{|c|c|c|c|c|}
\hline \multirow[b]{2}{*}{ Forms of Emergy } & \multicolumn{4}{|c|}{ Typical Phystaal Quantities } \\
\hline & $\begin{array}{l}\text { State Variable } \\
\text { (static, } \\
\text { across' variable) }\end{array}$ & $\begin{array}{l}\text { Flow Variable } \\
\text { (dynamic, } \\
\text { through" variable) }\end{array}$ & $\begin{array}{l}\text { Power }(=\text { state } \times \text { flow variables }) \\
P=d W / d f\end{array}$ & $\begin{array}{l}\text { Work } \\
W=f P \cdot d t\end{array}$ \\
\hline Mechanical translational & force $F$ & $\begin{array}{l}\text { velocity } \\
\qquad y=d s / d f\end{array}$ & $P=F_{t} d s / d f=F_{+} V$ & $W=\int F \cdot y_{0} d t=\int F, d s$ \\
\hline Mechanical rototional & $\begin{array}{l}\text { torque } \\
\qquad H=F_{H}\end{array}$ & $\begin{array}{l}\text { angular velocity } \\
\qquad \omega=d \alpha d t\end{array}$ & $P=M_{t} l=F_{*} d a / d f$ & $W=\int N_{0} \omega d t=\int M d \alpha$ \\
\hline Fluid & $\begin{array}{l}\text { pressure } \\
\qquad p=F / A\end{array}$ & $\begin{array}{l}\text { volume flow rote } \\
\qquad \begin{array}{l}\theta \\
=\end{array} / d t \\
\text { mass flow rate } \\
\qquad=d m / d t\end{array}$ & $\begin{array}{l}p=\Delta \rho \cdot d V / d t \\
p=\Delta \rho \cdot m / \rho\end{array}$ & $\begin{array}{l}W=J \Delta p \cdot d V \\
W=\rho \Delta p \cdot m \cdot d t / \rho=\rho \Delta \rho \cdot d m / \rho\end{array}$ \\
\hline Electricol & $\begin{array}{r}\text { voltoge } \\
\text { u }\end{array}$ & $\begin{array}{l}\text { electric eurrent } \\
\qquad t=d Q / d f\end{array}$ & $P=U_{t} t=U_{t} d Q / d t$ & $W=r U t d t=r v_{0} d Q$ \\
\hline Thermal & $\begin{array}{c}\text { temperoture } \\
r\end{array}$ & $\begin{array}{l}\text { entropy } \\
\qquad \xi=d S / d t\end{array}$ & $P=\Delta T S=\Delta T \cdot d S / d f$ & $w=\Lambda \triangle r \cdot s \cdot d t=f \triangle I \cdot d s$ \\
\hline
\end{tabular}

Figure 4 Forms of Energy and Quantities [16] 
Machine elements, redefined as design elements [14], are carriers of a (simple or more complex) function, have active connections (action locations) to other constructional parts of a working technical system, and provide connections among the action locations on each constructional part. An elemental organ consists of a pairing of action locations on two interacting constructional parts. Design elements are organisms. According to Weber [14], the verbs of their function (i.e. as flows) are mainly (1) transmit, (2) reduce/increase, (3) connect/disconnect, (4) store, (5) divide/unite, (6) transform, (7) distribute/combine, (8) distribute/collect, (9) separate/mix, and many others.

Engineering Design Science [13] recognizes four kinds of transformation processes that change the properties of an operand: (A) processing to change structure, (B) manufacturing to change form, (C) transporting to change location, and (D) storing to change the time coordinate. These can be applied to four kinds of operands: (a) materials, (b) energy, (c) information/signals, and (d) humans and other living things (a special kind of material), giving 16 'pure' transformations - and many more combinations. Operand (d), consisting of humans and other living things, is only applicable to the purpose of technical systems of complexity levels III and IV. Figure 5 show how some of the verbs used by Weber relate to transformations of various kinds of operands.

\begin{tabular}{|c|c|c|c|c|c|}
\hline \multirow{2}{*}{\multicolumn{2}{|c|}{$\begin{array}{l}\text { TRANSFORMATION } \\
\text { PROCESS (TrFP) }\end{array}$}} & \multicolumn{4}{|c|}{ TRANSFORMATION } \\
\hline & & \multirow{2}{*}{\begin{tabular}{|l} 
of structure \\
PROCESSING
\end{tabular}} & \multirow{2}{*}{$\begin{array}{l}\text { of form } \\
\text { MANUFACTURING }\end{array}$} & \multirow{2}{*}{\begin{tabular}{|l}
$\begin{array}{l}\text { of space } \\
\text { coordinate }\end{array}$ \\
TRANSPORTING
\end{tabular}} & \multirow{2}{*}{\begin{tabular}{|l} 
of time \\
coordinate
\end{tabular}} \\
\hline & & & & & \\
\hline \multirow{8}{*}{ 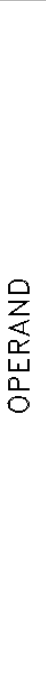 } & $\begin{array}{c}\text { Material } \\
M\end{array}$ & $\begin{array}{l}M \text { convert } \\
\text { (process) }\end{array}$ & $\begin{array}{l}\text { M transform } \\
\text { (farm, shape) }\end{array}$ & M transpart & M store \\
\hline & e.g. & $\begin{array}{c}\text { iron ore } \\
-->\text { steel }\end{array}$ & \begin{tabular}{|l|} 
scontling \\
$-->$ workpiece
\end{tabular} & $\begin{array}{l}\text { workpiece in } \\
\text { storage bin } \\
-- \text { wp on } \\
\text { assembly line }\end{array}$ & $\begin{array}{l}\text { workpiece in } \\
\text { storage bin }\end{array}$ \\
\hline & $\underset{E}{E n e r g y}$ & E convert & E transform & E transport & E store \\
\hline & e.g. & $\begin{array}{l}\text { hydraulic } \\
-\rightarrow>\text { electrical }\end{array}$ & $\begin{array}{l}50000 \mathrm{~V} \\
-->220 \mathrm{~V}\end{array}$ & $\begin{array}{l}\text { power station } \\
-->\text { consumer }\end{array}$ & $\begin{array}{l}\text { in accumulator } \\
\text { (battery, spring) }\end{array}$ \\
\hline & $\begin{array}{c}\text { Information } \\
1\end{array}$ & 1 convert & $\begin{array}{l}\text { I transform } \\
\text { (translate) }\end{array}$ & I transport & I store \\
\hline & e.g. & $\begin{array}{l}\text { graphical } \\
-\rightarrow>\text { digital }\end{array}$ & $\begin{array}{l}\text { German text } \\
-\rightarrow \text { English }\end{array}$ & $\begin{array}{c}\text { news sender } \\
-->\text { receiver }\end{array}$ & $\begin{array}{l}\text { speech on } \\
\text { magnetic tope }\end{array}$ \\
\hline & $\begin{array}{c}\text { Human (animal) } \\
\mathrm{Hu}(\mathrm{L})\end{array}$ & Hu convert & Hu transform & Hu transport & Hu store \\
\hline & e.g. & $\stackrel{\text { sick }}{-\rightarrow}$ healthy & $\begin{array}{l}\text { natural hand } \\
-\rightarrow \text { prosthesis }\end{array}$ & $\begin{array}{c}\text { in London } \\
-->\text { in Toronto }\end{array}$ & $\begin{array}{l}\text { at home (in } \\
\text { bed) }\end{array}$ \\
\hline & $\begin{array}{l}\text { ypical verbs } \\
\text { f operand } \\
\text { ransformation } \\
\text { of of TS-internal } \\
\text { unction }\end{array}$ & $\begin{array}{l}\text { convert, } \\
\text { rectify, } \\
\text { oscillate, } \\
\text { process }\end{array}$ & $\begin{array}{l}\text { enlarge } \\
\text { increase, reduce } \\
\text { connect, separate } \\
\text { join, divide } \\
\text { collect, diffuse } \\
\text { combine, dissipate } \\
\text { connect, interrupt } \\
\text { couple, disconnect } \\
\text { emit, absorb } \\
\text { manufacture } \\
\text { produce. }\end{array}$ & $\begin{array}{l}\text { conduct, isolote } \\
\text { guide, release }\end{array}$ & $\begin{array}{l}\text { store, retrieve } \\
\text { hold, release } \\
\text { keep, reject }\end{array}$ \\
\hline
\end{tabular}

Figure 5 Basic Classification of Transformation Processes and Technical Processes [15]

Comparing [14] with [13]: (4) 'store' is a transformation in time; (1) 'transmit' is a transformation in location, and is often a special case of 'reduce/increase'; (3) 'connect/disconnect' is a special case of 'transmit'; (2) 'reduce/increase' is a special case of 'transform', from one form to the same form; (6) 'transform' is a transformation of form; (5) 'divide/unite' is a transformation of structure. (2) 'reduce/increase' can be accomplished by serial application of two 'transform' operations, e.g. mechanical rotation to hydrodynamic flow to mechanical rotation, as in fluid couplings.

A systematic classification of design elements (in general) according to functions (augmented from [14]) is shown in figures 6 and 7. More extensive classifications may become too complex for human searching (compare design catalogs $[15,16,17])$, and may be better implemented in computer-resident form, e.g. using hypermedia [18]. Such a structure of information, adapted to mechanical couplings, may show many dimensions, see figure 8. Energy transfer (in such coup- 


\begin{tabular}{|c|c|c|c|c|}
\hline \multirow{2}{*}{$\begin{array}{l}\text { Forms of } \\
\text { Energy }\end{array}$} & \multicolumn{4}{|c|}{ "Function" Verbs } \\
\hline & transmit & reduce/increase & $\begin{array}{l}\text { connect/ } \\
\text { disconnect }\end{array}$ & store \\
\hline $\begin{array}{l}\text { Mechanicol } \\
\text { tronsiotional }\end{array}$ & $\begin{array}{l}\text { rods, links, } \\
\text { cobles, belts, } \\
\text { choins, connection } \\
\text { elements (e.g. } \\
\text { connecting rod), } \\
\text { guidances, ... }\end{array}$ & $\begin{array}{l}\text { levers, wedges, } \\
\text { pistons, ... }\end{array}$ & $\begin{array}{l}\text { rotchet mechanisms, } \\
\text { troction couplings, } \\
\text { mechanical } \\
\text { flip-flops, } \\
\text {... }\end{array}$ & $\begin{array}{l}\text { springs ('stotic' } \\
\text { strain energy), } \\
\text { counter-weights } \\
\text { 'static' potential } \\
\text { energy), inertio } \\
\text { mosses ('oymomic' } \\
\text { kinetic energy), ... }\end{array}$ \\
\hline $\begin{array}{l}\text { Mechanical } \\
\text { rotational }\end{array}$ & $\begin{array}{l}\text { shafts, keys, } \\
\text { splines, serrations, } \\
\text { cotters, clamp } \\
\text { connections, force } \\
\text { and shrink fits, } \\
\text { couplings, bearings } \\
\text { (sliding, rolling), } \\
\text { guides, ... }\end{array}$ & $\begin{array}{l}\text { gears, belts, } \\
\text { timing belts, } \\
\text { chains, friction } \\
\text { drives, flat and } \\
\text { vee belts, ... }\end{array}$ & $\begin{array}{l}\text { clutches, brakes, } \\
\text {... }\end{array}$ & $\begin{array}{l}\text { torsion } \\
\text { springs ('static'), } \\
\text { flywheels } \\
\text { ('dynomic') } \\
\text {.. }\end{array}$ \\
\hline $\begin{array}{l}\text { Hydrostotic } \\
\text { Pnesmatic }\end{array}$ & $\begin{array}{l}\text { pipes, tubes, } \\
\text { fittings, } \cdots\end{array}$ & & valves, $\ldots$ & $\begin{array}{l}\text { pressure vessels, } \\
\text { hydraulic acoum- } \\
\text { ulators, ... }\end{array}$ \\
\hline $\begin{array}{l}\text { Hydrodynamic } \\
\text { Aerodynamic }\end{array}$ & $\begin{array}{l}\text { vanes, guides, } \\
\text { wings, } \ldots\end{array}$ & diffusers, $\ldots$ & volves, $\ldots$ & \\
\hline Electrical & wires, fuses, ... & tronsformers & $\begin{array}{l}\text { insulation, switches, } \\
\text {... }\end{array}$ & $\begin{array}{l}\text { capacitors ("static'), } \\
\text { occumulotors, } \\
\text { inductors } \\
\text { ("dynomic'), ... }\end{array}$ \\
\hline $\begin{array}{l}\text { Electronic } \\
\text { (analog. } \\
\text { digital) }\end{array}$ & conductors, ... & $\begin{array}{l}\text { amplifiers, } \\
\text { ottenustors, } \\
\text { ohokes, } \\
\text { inductors, ... }\end{array}$ & $\begin{array}{l}\text { tronsistors, } \\
\text { diodes, ... }\end{array}$ & magnetic memory, ... \\
\hline Thermostatic & $\begin{array}{l}\text { heot pipes, } \\
\text { cooling fins, ... }\end{array}$ & meat exchangers, ... & $\begin{array}{l}\text { thermal insulation, } \\
\ldots\end{array}$ & $\begin{array}{l}\text { heat storage units } \\
\text { (fire-brick) }\end{array}$ \\
\hline Thermodynomic & $\begin{array}{l}\text { combustors, } \\
\text { sproy nozzles. ... }\end{array}$ & heot pumps, ... & $\begin{array}{l}\text { diverter channels, } \\
\ldots\end{array}$ & \\
\hline NOTE: & $\begin{array}{l}\text { special case of } \\
\text { "reduce/incredse' } \\
\text { if value and form of } \\
\text { output = input }\end{array}$ & $\begin{array}{l}\text { special cosse of } \\
\text { "tronsform" } \\
\text { if form of } \\
\text { output = input }\end{array}$ & "tronsmito & \\
\hline
\end{tabular}

Figure 6 Classification of Design Elements for some 'Function' Verbs [16]

lings, and elsewhere) mainly takes place at action location pairings (organs) by different manifestations of closure as shown in figure 9 , and these form an information unit in the hypermedia classification system. Consequently, various existing couplings can be classified in a matrix as shown in figure 10. A search for existing coupling principles according to various criteria is thus possible.

\section{Machine Elements - Synthesis Considerations}

It is also possible (and was demonstrated [19]) to search out new principles, and to use systematic variation, especially of active organs and constructional details. According to check lists $[15,16]$, variations can be: (a) of form, (b) of position or orientation, (c) of number, (d) of size/dimension, (e) of sequence or arrangement, (f) of connecting structure, (g) of connection type, $(\mathrm{h})$ of contact type, (i) of mobility, or (j) of constraint. Examples of these variations are shown in figure 11. Many patents have been issued on this basis.

Such systematic classification and variation obviously assists (personal, individual and group) creativity, they can produce many hundreds to thousands of possible alternatives. These methods obviously also increase demands for suitable selection and evaluation of alternatives to find those combinations that show technical and economic merit. Capability of a designer to use such systematic variation is probably also essential for the New Century.

Engineering education should obviously include education about machine (design) elements. Ideally, this should involve a survey of possible manifestations of all kinds of design elements, a consideration of design processes for such elements, and indications about analytical investigations of their properties. Too much emphasis has been placed on mathematical modeling and analysis, the needs for design are urgent.

When designing a new technical system (i.e. not just minor modifications to an existing device), the first priority for the engineering designer should usually be to establish the purpose of the device, what it should be used for [15]. The second step should be to establish (with possible alternatives) what outputs are needed from the technical system. The third step should then be to establish (with alternatives) what the technical system should be capable of doing to produce the outputs [14], 


\begin{tabular}{|c|c|c|c|c|c|c|c|c|c|}
\hline $\begin{array}{l}\text { Forms } \\
\text { of } \\
\text { Energy } \\
\text { Transfor } \\
\text { from: }\end{array}$ & 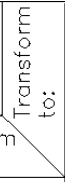 & 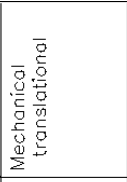 & 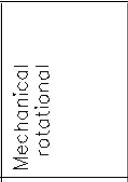 & 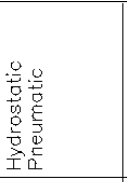 & 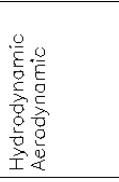 & 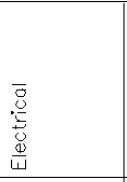 & $\begin{array}{l}.0 \\
\frac{0}{2} \\
0 \\
0 \\
0 \\
0 \\
\frac{0}{\square} \\
\end{array}$ & 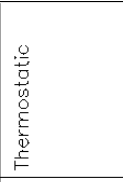 & 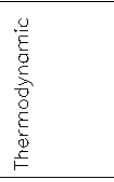 \\
\hline $\begin{array}{l}\text { Mechanic } \\
\text { tronslat }\end{array}$ & onol & $\begin{array}{l}\text { (see } \\
\text { ineduce/, } \\
\text { increase) }\end{array}$ & $\begin{array}{l}\text { wheels, } \\
\text { rack and } \\
\text { pinion, } \\
\text { slider- } \\
\text { crank, } \\
\text { motion } \\
\text { screws }\end{array}$ & $\begin{array}{l}\text { cylinder/ } \\
\text { piston }\end{array}$ & & $\begin{array}{l}\text { linear } \\
\text { generators }\end{array}$ & \begin{tabular}{|l|} 
linear \\
transducers \\
piezo, \\
lvdt, \\
strain \\
$\quad$ gage
\end{tabular} & $\begin{array}{l}\text { lineor } \\
\text { brokes }\end{array}$ & $\begin{array}{l}\text { recipro- } \\
\text { coting } \\
\text { gos } \\
\text { compres- } \\
\text { sors }\end{array}$ \\
\hline $\begin{array}{l}\text { Mechanio } \\
\text { rotation }\end{array}$ & & $\begin{array}{l}\text { wheels, } \\
\text { rock and } \\
\text { pinion, } \\
\text { slider- } \\
\text { crank, } \\
\text { motion } \\
\text { screws, } \\
\text { coms }\end{array}$ & $\begin{array}{l}\text { (see } \\
\text { reduce/, } \\
\text { increase') }\end{array}$ & $\begin{array}{l}\text { hydrostatic } \\
\text { pumps }\end{array}$ & $\begin{array}{l}\text { turbo- } \\
\text { pumps }\end{array}$ & $\begin{array}{l}\text { ratory } \\
\text { generatars }\end{array}$ & $\begin{array}{l}\text { rotary } \\
\text { transducers }\end{array}$ & $\begin{array}{l}\text { rotary } \\
\text { brakes }\end{array}$ & $\begin{array}{l}\text { rotory } \\
\text { gas } \\
\text { compres- } \\
\text { sors }\end{array}$ \\
\hline $\begin{array}{l}\text { Hydrosto } \\
\text { Pneumat }\end{array}$ & & $\begin{array}{l}\text { cylinder/ } \\
\text { piston }\end{array}$ & $\begin{array}{l}\text { mydrostatic } \\
\text { motors }\end{array}$ & $\begin{array}{l}\text { (see } \\
\text { reduce/s } \\
\text { increase") }\end{array}$ & & & $\begin{array}{l}\text { pressure } \\
\text { sensors, } \\
\text { specific } \\
\text { gravity } \\
\text { sensors }\end{array}$ & & \\
\hline $\begin{array}{l}\text { Hydrodyn } \\
\text { Aerodyno }\end{array}$ & $\begin{array}{l}\text { amic } \\
\text { tric }\end{array}$ & water jet & turbines & $\begin{array}{l}\text { pitot-statio } \\
\text { tubes, } \\
\text { fluidic } \\
\text { control } \\
\text { units }\end{array}$ & $\begin{array}{l}\text { (see } \\
\text { "reduce/, } \\
\text { increase') }\end{array}$ & $\begin{array}{l}\text { magneto- } \\
\text { hydro- } \\
\text { dynamic } \\
\text { generator }\end{array}$ & & throttles & \\
\hline Electrical & & $\begin{array}{l}\text { linear } \\
\text { motor, } \\
\text { actuator, } \\
\text { solenoid }\end{array}$ & $\begin{array}{l}\text { rotary } \\
\text { motor, } \\
\text { rotary } \\
\text { actugtor }\end{array}$ & $\begin{array}{l}\text { magneto- } \\
\text { hydro- } \\
\text { dynamic } \\
\text { pumps }\end{array}$ & & $\begin{array}{l}\text { (see } \\
\text { 'reduce/, } \\
\text { increase) }\end{array}$ & & $\begin{array}{l}\text { electrical } \\
\text { resiston- } \\
\text { ces }\end{array}$ & \\
\hline Electroni & & $\begin{array}{l}\text { mecho- } \\
\text { tronics }\end{array}$ & $\begin{array}{l}\text { mecho- } \\
\text { tronics }\end{array}$ & & & & $\begin{array}{l}\text { (see } \\
\text { reduce/ } \\
\text { increase) }\end{array}$ & & \\
\hline Thermost & atic & $\begin{array}{l}\text { linear heot } \\
\text { engines, } \\
\text { combustion } \\
\text { engines }\end{array}$ & $\begin{array}{l}\text { rotary heat } \\
\text { engines, } \\
\text { combustion } \\
\text { engines }\end{array}$ & & & & \begin{tabular}{|l|} 
heat \\
sensors, \\
temperature \\
sensars
\end{tabular} & $\begin{array}{l}\text { (see } \\
\text { 'reduce/ } \\
\text { increose) }\end{array}$ & \\
\hline \multicolumn{2}{|c|}{$\begin{array}{l}\text { Thermo- } \\
\text { dynomic }\end{array}$} & $\begin{array}{l}\text { turbojet } \\
\text { engines, } \\
\text { turboprop } \\
\text { engines, } \\
\text { ramjets }\end{array}$ & $\begin{array}{l}\text { gas turbine } \\
\text { engines }\end{array}$ & & & & & & $\begin{array}{l}\text { (see } \\
\text { reduce/ } \\
\text { increase) }\end{array}$ \\
\hline
\end{tabular}

Figure 7 Classification of Design Elements for 'Function' Verb 'Transform' [16]

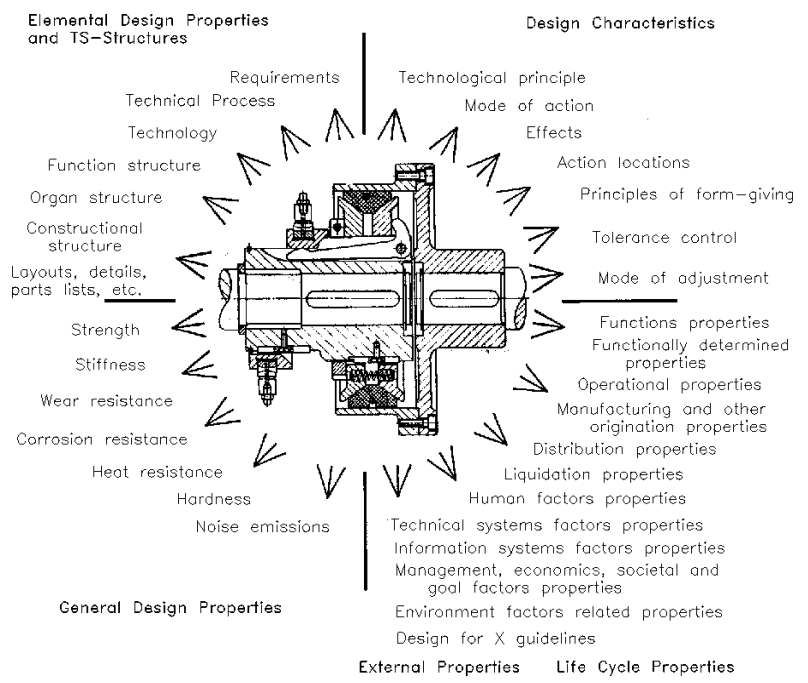

Figure 8 Machine Elements and Related Information [20] 


\begin{tabular}{|c|c|c|c|}
\hline & \multicolumn{3}{|c|}{ Type of Closure Principle } \\
\hline & \multicolumn{2}{|c|}{ Form Closure } & \multirow{2}{*}{ 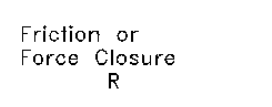 } \\
\hline & Rigid Contgets & Flexible Contact & \\
\hline $\begin{array}{l}\text { Iconic } \\
\text { Representation }\end{array}$ & & & $\frac{f_{1}}{F_{k_{-}}}$ \\
\hline Equation & $F_{N}=F$ & $F_{e 1}=c \cdot \Delta_{s}$ & $F_{R}=H_{H} \cdot F_{2}$ \\
\hline $\begin{array}{l}\text { Types of Stress } \\
\text { on Materials and } \\
\text { Surfaces }\end{array}$ & $\begin{array}{l}\text { Surface pressure, } \\
\text { Hertz contact } \\
\text { stresses, } \\
\text { Sub-surfoce shear } \\
\text { stresses }\end{array}$ & $\begin{array}{l}\text { Surface pressure } \\
\text { Elastic/plastic } \\
\text { deformation }\end{array}$ & $\begin{array}{l}\text { Surface pressure, } \\
\text { Surface shear stresses, } \\
\text { Static friction (limited), } \\
\text { Weor }\end{array}$ \\
\hline $\begin{array}{l}\text { Properties and } \\
\text { Design } \\
\text { Characteristics }\end{array}$ & $\begin{array}{l}\text { With clearance: } \\
\text { shock, } \\
\text { plastic defor- } \\
\text { mation } \\
\text { Without clearance: } \\
\text { pre-lood stresses, } \\
\text { high precision of } \\
\text { force trans- } \\
\text { mission }\end{array}$ & $\begin{array}{l}\text { Relative motion, } \\
\text { Rebound (elastic } \\
\text { strain energy), } \\
\text { Vibrations, } \\
\text { Damping, } \\
\text { Compensates peaks } \\
\text { of force appli- } \\
\text { cation }\end{array}$ & $\begin{array}{l}\text { Limited farce trans- } \\
\text { mission parallel } \\
\text { to contoct surface, } \\
\text { Micro-movement at } \\
\text { edge of contact } \\
\text { (danger of fretting) } \\
\text { Sliding when force } \\
\text { exceeds static limit }\end{array}$ \\
\hline
\end{tabular}

Figure 9 Closure Principles as Classification Criteria for Machine Elements [20]

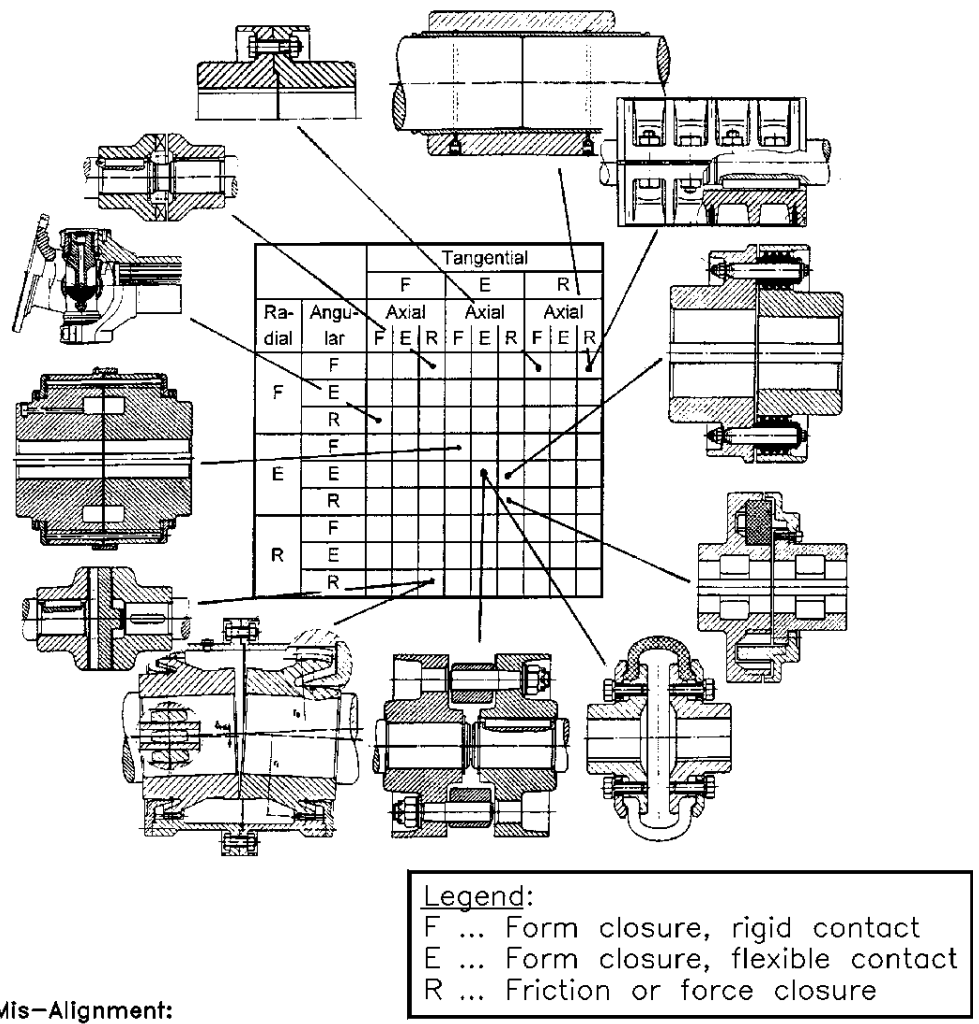

Types of Mis-Alignment:

Angular, intersecting axes Parallel axes

Skew, non-intersecting angular axes Axial displacement
Static, no substantial change during operation Dynamic, substantial change of offset and/or angle during operation

Figure 10 Classification of Couplings [20] 


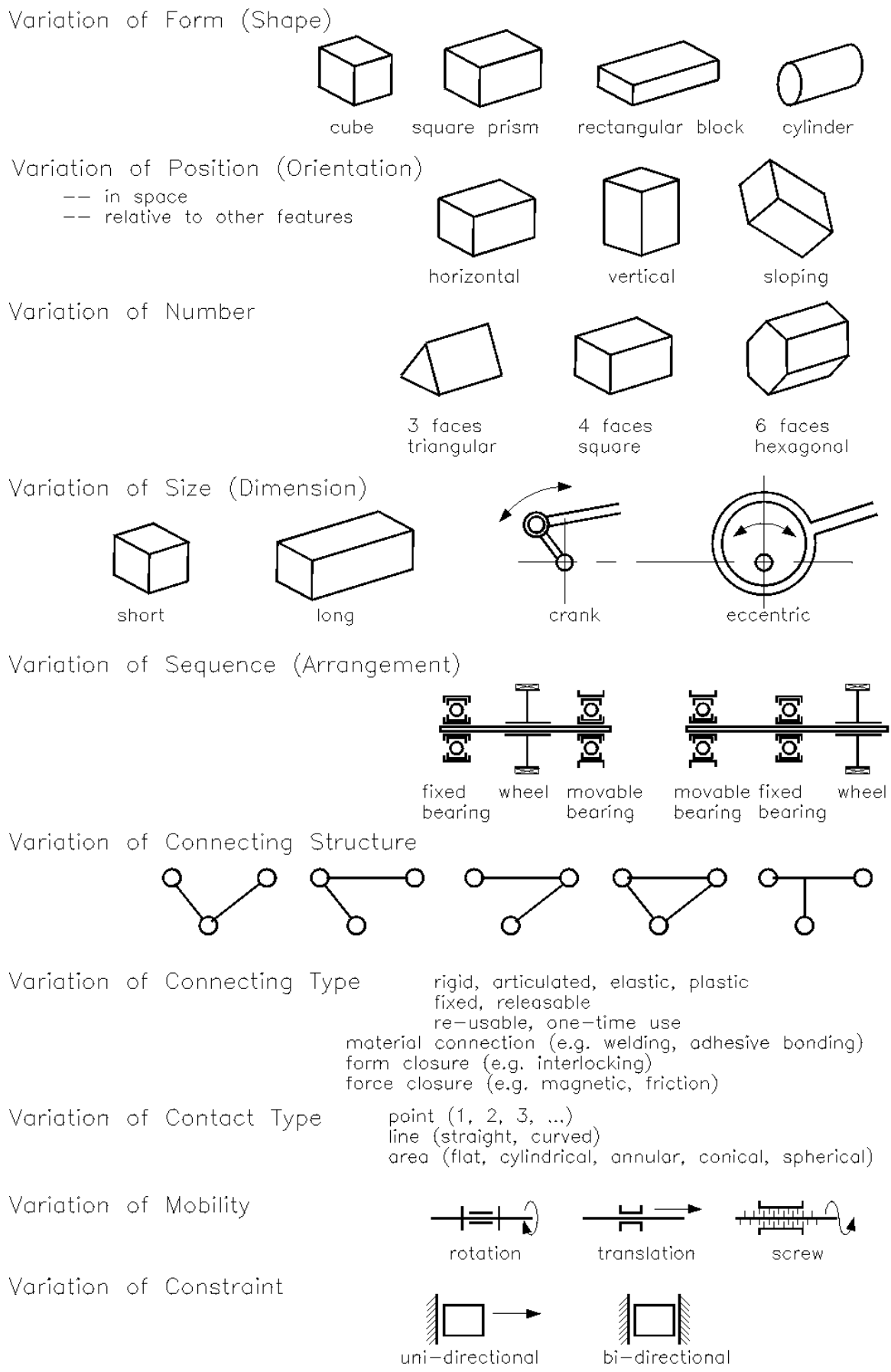

Figure 11 Possibilities for Variation [17,18]]

how it should work, its mode of internal action. Some simulation may be applicable at this point. From this information, the engineering designer can establish with what (in principle, and with alternatives) the internal actions can be made to happen. This is where the principles of operation of typical machine elements is useful, and classes of machine elements can be chosen to make the device work. As a consequence, typical sizes can be established, usually by order-of-magnitude estimations. Only when a sufficiently good layout (as general arrangement) has been developed in this way can better analytical tools be employed to verify the anticipated performance of the proposed technical system.

It follows that an encyclopedic knowledge of machine elements is useful in an early stage of design engineering, the full analysis only comes later. Should not the engineering curriculum, especially for machine elements, reflect this pattern of procedure in designing 
$[11,12,13]$ ? And should not the engineering sciences (in their analytical emphasis) also take into account the need for an understanding of and 'feel' for the phenomena, with 'quick and dirty' estimations, developing assumptions for an improved analysis, as well as the full analytical treatment?

\section{Closure}

The subject of Machine Elements needs urgent revision to reach across the conventional boundaries among engineering disciplines, and to include the more recent elemental systems. A wide survey of design elements will enable our students to function by giving them the knowledge about designing using machine elements, combined with the tools to analyze problems as concepts. There is still a need to use mathematical analysis, mainly as a tool to estimate required dimensions, and as an evaluation tool. In this way we can bring engineering education into a state where the requirements for the new century can be met.

\section{References}

[1] Doughtie, V.L. and Vallance, A. (1964) Design of Machine Members, New York: McGraw-Hil

[2] Faires, V.M. (1965) Design of Machine Elements (4 ed), New York: Macmillan

[3] Juvinall, R.C. and Marshek, K.M. (1991) Fundamentals of Machine Component Design (2 ed), New York: Wiley

[4] Spotts, M.F. (1985) Design of Machine Elements (6 ed), Englewood Cliffs, N.J.: Prentice-Hall

[5] ASEE (1955) Report on Evaluation of Engineering Education (L.E. Grinter, chairman), Jnl. Engng. Educ., Sept 1955 , p. 25-60

[6] Eder, W.E., (1995) 'Engineering Design - Art, Science and Relationships', Design Studies, 16, p. 117-127 1

[7] Eder, W.E. (2002a) 'Social, Cultural and Economic Awareness for Engineers', in CSME Forum 2002, Queen's University, Kingston, ON, abstract p 130, Proc on CD-ROM

[8] Eder, W.E. and Hosnedl, S. (2004a) 'Information - a Taxonomy and Interpretation', in Proc. International Design Conference - Design 2004, Dubrovnik, May 18 - 21, 2004, p. 169-176.

[9] Constant, E.W., II (1980) The Origins of the Turbojet Revolution, Johns Hopkins Studies in the History of Technology, Baltimore: Johns Hopkins U.P.

[10] Vincenti, W.G. (1990) What Engineers Know and How They Know It - Analytical Studies from Aeronautical History, Baltimore: Johns Hopkins Univ. Press

[11] Eder, W.E. (2002b) 'Education for Engineering and Designing', in Proc. International Design Conference - Design 2002, Dubrovnik, May 14 - 17, 2002, Proc. on CD-ROM

[12] Eder, W.E. (2004b) 'Reflections About Reflective Practice', in Proc. International Design Conference Design 2004, Dubrovnik, May 18 - 21, 2004, p. 177182.

[13] Eder, W.E. \& Hubka, V. (2001) 'Curriculum, Pedagogics, and Didactics for Design Education', in WDK 28, Proc. International Conference on Engineering Design, ICED01 Glasgow, 21-23 August 2001, Vol 4, pp 285-292

[14] Hubka, V. and Eder, W.E. (2001) 'Functions Revisited', International Conference on Engineering Design, 21-23
August 2001, in WDK 28 - Proc. ICED 01 Glasgow, Vol. 1, IMechE Paper C586/102, p. 69-76

[15] Hubka, V. and Eder, W.E. (1996) Design Science: Introduction to the Needs, Scope and Organization of Engineering Design Knowledge, London: SpringerVerlag, http://deed.ryerson.ca/DesignScience/

[16] Weber, C. and Vajna, S. (1997) 'A New Approach to Design Elements (Machine Elements)', in WDK 25 Proc. ICED 97 Tampere, Tampere University, Vol. 3, p. 685-690

[17] Ehrlenspiel, K. (1995) Integrierte Produktentwicklung, München: Carl Hanser Verlag

[18] Koller, R. (1985) Konstruktionslehre für den Maschinenbau (Study of Designing for Mechanical Engineering, 2. ed.), Berlin/Heidelberg: Springer-Verlag

[19] Roth, K. (1995) Konstruieren mit Konstruktionskatalogen (2 ed. 2 vols.) (Designing with Design Catalogs), Berlin/Heidelberg: Springer-Verlag (1 ed 1982)

[20] Birkhofer, H. (1997) 'The Power of Machine Elements in Engineering Design - A Concept of a Systematic, Hypermedia-Assisted Revision of Machine Elements', in WDK 25 - Proc. ICED 97 Tampere, Tampere University, Vol. 3, p. 679-684

[21] Ehrlenspiel, K. and John, T. (1987) 'Inventing by Design Methodology', in WDK13 - Proc. ICED 87 Boston, New York: ASME, Vol.1, p. 29-37 